\title{
Contributions to the resilience study of ATI medical staff
}

\section{Contribuţii la studiul rezilienţei la personalul medical ATI}

\author{
Rodica Eugenia SîRGHIE \\ Departamentul ATI, Spitalul de Copii „M.S. Curie“, București, România
}

\section{REZUMAT}

Stresul fizic și psihic susținut în cadrul activității profesionale a personalului ATI (în special la cadrele medicale) se poate solda cu un sindrom de suprasolicitare denumit sindrom burnout, desfășurat in trei faze: epuizare emoțională, depersonalizare și împlinire personală (scăzută). Reziliența reprezintă rezistența înnăscută (sau dobândită) a individului la stresul fizic sau psihic.

Scopul cercetării a fost stabilirea gradului de afectare al stresului asupra personalului medical în special din secțiile ATI și studiul rezilienței ca factor protector împotriva stresului.

Material și metode. Chestionarul de burnout Maslach și scala de reziliență Wagnell Young au fost aplicate la 300 de subiecți (lot probant: 75 medici ATI, 75 asistente ATI; lot martor: 75 medici alte specialități și 75 asistente alte specialități) proveniți din 11 spitale bucureștene, pe parcursul anului 2015.

Rezultate. Gradul de stres profesional relevă că cel mai puțin afectate de stresul profesional sunt asistentele de altă specialitate decât ATI, iar cel mai mult sunt afectați medicii ATI. Asistentele medicale sunt mai puțin afectate de dificultățile activității din secțiile ATI decât medicii ATI. Rezidenții (având o experiență redusă și o vulnerabilitate la stres crescută) sunt cei mai expuși la acțiunea nocivă a sindromului burnout. Reziliența este mai scăzută la personalul medical (medici și asistente) la care s-au înregistrat creșteri semnificative ale scalelor epuizare emoțională și depersonalizare ale chestionarului Maslach. Reziliența s-a dovedit a fi un veritabil factor tampon în fața stresului profesional.
\end{abstract}

Cuvinte cheie: sindrom burnout, stres profesional, reziliență

\begin{abstract}
The stress represents an adaptation reaction of the human body to external or internal factors, with the tendency to restore its balance, the negative effects of the stress being related to the actions of catecholamine and cortisone, to the decline of the gamma interferon secretion and NK cells inhibition. The physical and mental/ emotional stress sustained during a professional activity (especially by medical staff) can lead to an overloading syndrome, named burnout syndrome, with 3 (three) phases: emotional exhaustion, depersonalization and low personal fulfillment. Resilience represents the native resistance (or gained during the lifetime) of a person to physical or mental/emotional stress. The purpose of this research was to establish the effect of stress on the medical staff, especially ICU staff (Intensive Care Unit), and to study the resilience as protection against stress.

Materials and methods. Using Maslach burnout questionnaire and the resilience scale - questionnaires applied to 300 subjects (ICU batch: 75 ICU physicians, 75 ICU nurses; the witness batch: 75 physicians of other specialties and 75 nurses of other specialties) from 11 hospitals in Bucharest, during the year 2015. Were used SPSS program, Pearson correlations, Anova test and the descriptive data analysis function for the information collected from the subjects. We could notice significant statistic differences between the four sub-categories - as regarding the burnout scores for emotional exhaustion, depersonalization, professional fulfill-ment and resilience, with significance threshold less than 0,05.
\end{abstract}


Conclusion. Resilience is lower in case of medical staff (physicians and nurses) with significant increases of emotional exhaustion scale and depersonalization scale of Maslach questionnaire; nurses are less affected by the difficulties of the activities within ICU sections comparing to ICU physicians regarding the professional stress degree, the results revealed that the less affected by the professional stress are the nurses of other specialities; resilience turned out to be a real buffer as regarding the professional stress; resident physicians (with low experience and a high stress vulnerability) are the most exposed to the harmful action of the burnout syndrome.

Keywords: burnout syndrome, professional stress, resilience

\section{INTRODUCERE}

Stresul reprezintă o reacție de adaptare a organismului la acțiunea unor factori externi sau interni având tendința să restabilească echilibrul biologic, psihologic și social al organismului. Hans Selye (creatorul conceptului de stres) a delimitat tipurile de stres fizic, chimic, biologic și psihologic (1) și a dat o primă definiție: „Reacție a întregului organism față de acțiunea externă a unor agenți stresori de natură variată“.

Efectele nefavorabile ale stresului asupra organismului se manifestă prin acțiunea hormonilor de stres (2), dintre care menționăm: catecolaminele (adrenalina și noradrenalina) - cu efecte negative asupra aparatului cardiovascular, prin creșterarea alurii ventriculare, a tensiunii arteriale și a consumului de oxigen miocardic, și cortizolul - cu efect de creștere a agregării plachetare, cu risc trombogen și factor predispozant pentru apariția ulcerului, a obezității și a diabetului. Chiar și imunitatea poate fi afectată în sensul scăderii acesteia în stările depresive prin scăderea secreției de interferon gamma și inhibiția activității celulelor NK (3).

Stresul de la locul de muncă (stresul ocupațional) reprezintă unul dintre cele mai frecvente stresuri în ziua de azi și se manifestă în special la anumite categorii profesionale la care munca de zi cu zi le pune în pericol propria viață a profesioniștilor respectivi (militarii, scafandrii, geniștii etc.) sau deciziile luate în cursul desfășurării activității (medici, controlori de trafic aerian, personal din siguranța circulației) se pot solda cu pierderi de vieți omenești (4-11). În această ultimă categorie se încadrează și medicii și asistentele din secțiile de anestezie terapie intensivă (ATI), la care suprasolicitarea fizică și psihică susținută din cursul activității profesionale poate genera un stres cronic descris pentru prima oară de Christine Maslach (12) și denumit de aceeași autoare „sindrom burnout“ (SBO). Munca desfășurată într-un climat de mare tensiune emoțională și amplificată de insuccese neimputabile profesioniștilor respectivi (de exem- plu medicii din serviciile de oncologie, medicii ATI care îngrijesc pacienți cu boli incurabile sau pacienți aflați deasupra resurselor terapeutice) duce în cele din urmă la o stare de epuizare emoțională ce reprezintă primul stadiu al SBO, care se caracterizează printr-o oboseală generală (fizică și nervoasă) cu tentă depresivă, echivalentă cu o stare de epuizare descrisă cu mulți ani înainte de Kielholz (13). Cei aflați în această fază prezintă o serie de acuze: tulburări de somn, inapetență sau o iritabilitate cu exprimare redusă, dar persistentă. Dintre markerii biologici ai acestei stări menționăm creșterea interleukinei 6 , citokină prezentă în stările de inflamație (10).

Al doilea stadiu al sindromului burnout, denumit depersonalizare, este caracterizat de instalarea unui sentiment de insatisfacție față de propria profesie și ea poate să conducă la apariția unei veritabile fobii față de locul de muncă, atitudinea medicului afectat în acest fel fiind marcată de o insensibilitate, atitudine rece și chiar cinică față de bolnavi.

Cel de-al treilea stadiu al sindromului burnout il reprezintă scăderea împlinirii personale/ personal accomplishment și constituie o rezultantă a acțiunii combinate a acelorași factori cauzali. În această ultimă etapă se produce deteriorarea autostimei medicului, ca o consecință a modificărilor de ordin psihologic, dar și din cauza simptomelor psihosomatice sau chiar psihiatrice apărute în cadrul SBO (10). Dar, de cele mai multe ori, această scădere a randamentului profesional se reflectă doar prin mici omisiuni sau greșeli la limita malpraxisului, întrucât persoana afectată compensează aceste neajunsuri printro mobilizare excesivă, costisitoare sub aspectul energiei de stres, a resurselor cognitive, afective și mai ales voliționale ale medicului afectat.

Există persoane care, de-a lungul timpului, au făcut față cu succes unor stresuri uriașe, cu amenințări asupra integrității fizice și psihice, inclusiv la adresa vieților, dar au trecut cu succes peste aceste obstacole și au ajuns la vârste înaintate. Una dintre resursele psihologice capabile să protejeze personalul medical de efectele de- 
vastatoare ale stresului îl reprezintă reziliența, definită ca o „capacitate a persoanei de a supraviețui, chiar de a se dezvolta, în urma unei acțiuni distructive la care a fost expusă“ și se concretizează prin „abilități de adaptare ale persoanelor expuse acelorași riscuri sau adversități“ (14). Reziliența permite persoanei sau grupului o adaptare la situații dificile deosebite, iar reușita adaptării implică o dezvoltare a personalității.

\section{SCOPUL CERCETĂRII}

Creșterea alarmantă a gradului de îmbolnăvire a personalului medical din secțiile ATI m-a determinat să încerc să determin gradul de afectare al stresului (în special al sindromului burnout) asupra personalului medical din secțiile de terapie intensivă ale mai multor spitale bucureștene în comparație cu alte specialități, precum și factorii protectori împotriva acestui sindrom - reziliența.

\section{OBIECTIVELE CERCETĂRII}

a) Decelarea semnelor de instalare la personalul ATI a SBO, în diversele sale stadii, cu raportarea la alte specialități medicale.

b) Studiul nivelului rezilienței la personalul ATI, ca premiză profilactică a protecției față de stresul ocupațional și a SBO.

c) Conștientizarea de către înșiși subiecții acestei cercetări a propriilor riscuri și veritabilele pericole la care sunt expuși zi de zi în cadrul activității epuizante pe care o desfășoară.

\section{IPOTEZELE CERCETĂRII}

a) Reziliența este mai scăzută la personalul ATI (medici și asistenți medicali), la care s-au înregistrat creșteri semnificative ale scalelor epuizare emoțională (EE) și depersonalizare (DP) ale chestionarului Maslach.

b) Reziliența este mai crescută la personalul ATI cu scoruri mici la scalele Epuizare emoțională și Depersonalizare (chestionarul Maslach), dar având vârste și vechime mai mari, ceea ce ar putea sugera faptul că medicii care lucrează mai mult timp într-o secție ATI și nu sunt afectați de apariția SBO ar putea avea un nivel inițial crescut al rezilienței ca factor de rezistență la stresul profesional.

\section{MATERIAL ȘI METODE}

Studiul a fost efectuat pe un lot de 300 de subiecți, dintre care 75 de medici ATI, 75 de asistente ATI și lotul martor format din 75 de medici alte specialități și 75 de asistente alte specialități. Vârstele subiecților au variat între 22 și 72 de ani, iar vechimea în muncă între 1 și 43 de ani. S-a încercat menținerea unui echilibru în componența grupurilor, în sensul că s-a menținut un procent asemănător în ceea ce privește raportul între seniori (cadre medicale cu activitate medicală mai mare de $10 \mathrm{ani}$ ) și juniori (cadre medicale cu mai puțin de 10 ani experiență) în cadrul fiecăreia dintre cele 4 subloturi. În ceea ce privește strategia de selecție a lotului de subiecți care au răspuns la mai multe chestionare, aceștia au provenit din 11 spitale bucureștene, dintre care 8 de stat și 3 cu caracter privat și, într-o altă clasificare, 5 multidisciplinare și 6 monodisciplinare. Orizontul de timp aferent culegerii datelor s-a desfășurat pe parcursul anului 2015, iar răspunsurile cadrelor medicale reprezintă efectele stresului în condiții obișnuite de muncă ale subiecților incluși în cercetare. Chestionarele distribuite în alte 2 spitale bucureștene nu au mai fost incluse în studiu deoarece personalul medical din aceste spitale de urgență nu a mai dispus de timpul efectiv necesar completării unor chestionare în condițiile apariției unui eveniment medical cu implicare directă și de prim plan a secțiilor de ATI - „Dezastrul din 30 octombrie 2015 - Colectiv".

Au fost folosite:

1) Inventarul de burnout Maslach (Maslach Burnout Inventory), ce evaluează tulburările care apar cel mai frecvent la personalul medical, având trei scale - EE (epuizare emoțională) - 8 itemi; DP (depersonalizare) -5 itemi; PA (împlinire profesională) -9 itemi;

2) Scala de reziliență Wagnell Young, care cupride 15 itemi referitori la atitudinea optimistă, de încredere în propriile posibilități și la rezistența subiecților față de adversitățile vieții.

Rezultatele au fost analizate prin aplicarea programului SPSS, focalizat pe analiza diferențelor semnificative dintre mediile obținute de cele 4 subgrupe în raport cu scorul obținut de întreg lotul de subiecți. În scopul prelucrării datelor am folosit, de asemenea, corelații Pearson, testul Anova și funcția de analiză descriptivă a datelor. 


\section{REZULTATE ȘI DISCUŢII}

În Tabelele 1 și 2 figurează rezultatele studiului.

Se observă diferențe semnificative statistic între cele patru subgrupuri de subiecți - medici ATI, medici alte specialități, asistenți medicali ATI, asistenți medicali alte specialități - în ceea ce privește scorurile burnout epuizare emoțională, burnout depersonalizare, burnout înplinire profesională și reziliență la un prag de semnificație mai mic decât 0,05.

Astfel, la scalele burnout epuizare și depersonalizare, medicii și asistenții medicali ATI înregistrează scorurile cele mai ridicate, la fel și medicii de alte specialități, în timp ce asistenții medicali de alte specialități obțin scoruri foarte scăzute în raport cu media scorurilor pe întreg lotul de subiecți (Tabelul 1).

Explicația ar consta în faptul că atât medicii cât și asistentele ATI au un număr mare de ore lucrate comparativ cu celelalte categorii și se confruntă mult mai frecvent cu situații dificile care le amplifică starea de stres.

La burnout depersonalizare, medicii ATI obțin scoruri foarte ridicate, iar asistenții medicali de la celelalte specialități (nonATI) - scoruri foarte scăzute în raport cu media pe întregul lot.

În cazul scorurilor la scala depersonalizare, diferențele obținute de către medicii ATI se accentuează extrem de semnificativ față de scorurile obținute de către medicii specialitățile nonATI și acest rezultat își are explicația în faptul că epuizarea medicilor ATI - deja mai crescută - se conjugă cu implicațiile negative asupra personalităților ale specificului profesiei: confruntarea frecventă cu cazuri la limita supraviețuirii, responsabilitatea apăsătoare și teama de eșec, interacțiunile cu aparținătorii - toate acestea conducând la modificări ale personalității lor precum „anestezie emoțională“, cinism etc.
La burnout împlinire profesională, medicii ATI și de alte specialități înregistrează scoruri mai scăzute (implicit performanțele profesionale cele mai scăzute), în timp ce asistenții medicali de alte specialități obțin cele mai ridicate scoruri în raport cu media scorurilor pe întreg lotul de subiecți (Tabelul 1). Durata foarte mare de timp până când un medic ajunge la apogeul carierei, perioadă presărată cu lipsuri (atât în ceea ce privește materialele și dispozitivele necesare desfășurării activității de zi cu zi cât și confortul personal în afara spitalului) - toate acestea duc la un scor de împlinire profesională mai scăzut la medici comparativ cu lotul de asistente.

Referitor la scorurile obținute la scala de reziliență, scorurile medicilor ATI sunt cele mai scăzute.

Asistenții medicali ATI și de alte specialități obțin scoruri ridicate în raport cu media scorurilor pe întreg lotul de subiecți. Reziliența scăzută la medici ar putea fi explicată prin faptul că aceștia au perioade de activitate mult prelungite - legislația din țara noastră prevede că garda este de 18-24 ore, iar după gardă medicul poate pleca acasă doar dacă activitatea medicală a secției se poate desfășura în condiții optime. Din păcate, în ziua de azi, când exodul personalului medical către țările vestice este tot mai accentuat, prea puține sunt spitalele în care medicii își pot permite luxul de a pleca acasă imediat după gardă.

În urma aplicării testului statistic ANOVA se observă diferențe semnificative statistic între grupul seniorilor și cel al juniorilor în ceea ce privește mediile la scorurile obținute la variabilele independente burnout epuizare și burnout împlinire profesională, la un prag de semnificație de 0,05 (Tabelul 2).

TABELUL 1. Mediile obținute la scalele SBO și reziliență

\begin{tabular}{|l|c|c|c|c|c|}
\hline Scale & \multicolumn{5}{|c|}{ Media pe subgrupuri } \\
\hline & $\begin{array}{c}\text { medici } \\
\text { ATI }\end{array}$ & $\begin{array}{c}\text { medici alte } \\
\text { specialități }\end{array}$ & $\begin{array}{c}\text { asistenți } \\
\text { medicali ATI }\end{array}$ & $\begin{array}{c}\text { asistenți medicali } \\
\text { alte specialități }\end{array}$ & $\begin{array}{c}\text { Medie } \\
\text { total }\end{array}$ \\
\hline Burnout epuizare & $\underline{\mathbf{2 9 , 3 9}}$ & $\underline{\mathbf{2 8 , 6 5}}$ & $\underline{\mathbf{2 9 , 5 9}}$ & $\mathbf{2 1 , 4 8}$ & $\mathbf{2 7 , 2 8}$ \\
\hline $\begin{array}{l}\text { Burnout } \\
\text { depersonalizare }\end{array}$ & $\underline{16,55}$ & 12,63 & 11,19 & $\mathbf{9 , 2 9}$ & 12,41 \\
\hline $\begin{array}{l}\text { Burnout împlinire } \\
\text { profes. }\end{array}$ & $\mathbf{4 4 , 0 1}$ & $\mathbf{4 4 , 5}$ & 46,65 & $\underline{49,03}$ & 46,05 \\
\hline Reziliență & $\mathbf{8 5 , 5 9}$ & $\mathbf{8 5 , 7 3}$ & 88,61 & $\underline{89,93}$ & 87,47 \\
\hline
\end{tabular}

Legendă tabel:

Scoruri ridicate - cifre subliniate

Scoruri scăzute - cifre bolduite, italice 
TABELUL 2

\begin{tabular}{|l|c|c|c|}
\hline & \multicolumn{3}{|c|}{ Media pe subgrupuri } \\
\hline & juniori & seniori & Medie total \\
\hline Burnout epuizare & $\underline{29,21}$ & $\mathbf{2 6 , 0 2}$ & 27,28 \\
\hline $\begin{array}{l}\text { Burnout împlinire } \\
\text { profesională }\end{array}$ & $\mathbf{4 4 , 9 7}$ & $\underline{46,75}$ & 46,05 \\
\hline
\end{tabular}

Legendă tabel:

Scoruri ridicate - cifre subliniate

Scoruri scăzute - cifre bolduite, italice

Astfel, juniorii obțin scoruri semnificativ mai mari decât seniorii la variabila burnout epuizare, în timp ce la burnout împlinire profesională juniorii înregistrează scoruri mai scăzute decât seniorii. Explicația probabilă ar fi lipsa de rezistență emoțională - frecventă la debutanți, în fața climatului specific ATI, dominat de solicitarea unor rezerve de compasiune dar și de necesitatea îndeplinirii unor sarcini dificile cu consum nervos excesiv.

\section{CONCLUZII}

În urma studiului efectuat se confirmă ipoteza că reziliența este mai scăzută la personalul medical ATI (medici și asistente) la care s-au înregistrat creșteri semnificative ale scalelor epuizare emoțională și depersonalizare ale chestionarului Maslach. Nu putem să atribuim un rol aproape exclusiv rezilienței scăzute a celor afectați de stresul ocupațional din unitățile ATI fără să luăm în considerare numeroșii factori organizaționali și psihosociali ce supun profesioniștii la o presiune biopsihologică extremă. Reziliența este mai crescută la personalul ATI cu scoruri mici la scalele EE și DP și având vârste și vechime mai mari, ceea ce ar putea sugera faptul că subiecții care activează îndelungat în secțiile ATI și nu declanșează sindromul burnout ar putea avea un nivel inițial crescut al rezilienței ca factor de rezistență la stresul profesional.

Fragilitatea emoțională a rezidenților ar $\mathrm{fi}$ un aspect important de semnalat deoarece aceștia sunt mai expuși factorilor specifici clima- tului de muncă din ATI din cauza lipsei antrenamentului, pe de o parte, și consumului energiei de stres pe parcursul unei pregătiri universitare îndelungate - ceea ce constituie o serioasă predispoziție pentru un insucces în adaptarea la rigorile și mai ales la suprasolicitările din ATI.

Asistentele medicale sunt mai puțin afectate de dificultățile activității din secțiile ATI, deși volumul lor de muncă este cel puțin similar cu cel al medicilor. Acest fapt ne sugerează ideea că elementul cel mai important în apariția disstresului profesional la medicii ATI este legat de responsabilitatea lor medicală și morală decurgînd din atributele profesionale, ea fiind majoră în raport cu atribuțiile și responsabilitățile asistentelor.

Comparația în ceea ce privește gradul de stres profesional relevă că cel mai puțin afectate de stresul profesional sunt asistentele de altă specialitate.

Reziliența s-a dovedit a fi un veritabil factor tampon în fața stresului profesional - un argument în acest sens fiind faptul că există numeroși medici cu activitate stresantă și care depășesc 20 de ani vechime fără să dezvolte sindromul burnout.

Concluzia finală cea mai importantă a cercetării noastre este că vulnerabilitatea la stres a rezidenților - obligați să intre rapid într-o activitate extrem de solicitantă - alături de o serie de carențe de ordin organizațional și mai ales alături de o reziliență scăzută constituie cauzele majore ale instalării unui stres intens de suprasolicitare pasibil de a favoriza instalarea precoce a sindromului burnout.

Considerăm că este necesară adoptarea unui complex de măsuri privind consilierea psihologică a rezidenților imediat după intrarea lor în activitatea ATI, consiliere bazată pe o testare psihologică multiplă, din care determinarea rezilienței lor poate constitui o veritabilă promisiune pentru parcurgerea cu succes a drumului profesional, fără accidente de tipul sindromului burnout.

Conflict of interest: none declared Financial support: none declared

\section{BIBLIOGRAFIE}

1. Selye H. (1956), The stress of life, McGraw-Hill Book, New York.

2. Coculescu M. (1991), Neuroendocrinologie, Ed. Acad.

3. lamandescu I.B. (2002), Stresul psihic din perspectivă psihologică și psihosomatică, Ed. Infomedica, București.
4. Trif A.B. (2000), The burnout syndrome, Buletinul informativ al Asociatiei Balint din Romania, nr. 5, March 2000, p 11-12.

5. Trif A.B. (2000), The burnout syndrome, Buletinul informativ al Asociatiei Balint din Romania, nr. 5, March 2000, p 11-12.
6. Tantiverdi O. (2013), A medical oncologist's perspective on communication skills and burnout syndrome with psycho-oncological approach (to die with each patient one more time: the fate of the oncologists), Med Oncol. Jun; 30(2):530. doi: 10.1007/ s12032-013-0530-y. Epub 2013 Mar 15. 
7. Palmer R.G., Spaid W.M. (1996), Authoritarianism, inner/other directedness, and sensation seeking în firefighter/ paramedics: Their relationship with burnout. Prehospital and Disaster Medicine, I I (1), 11-15.

8. Schaufeli W., Maslach C., Marek T. (1993), Professional burnout: Research developments în theory and research, Taylor \& Francis, Washington, D.C.

9. Hagău N., Pop R.S. (2012), Prevalence of burnout în Romanian anesthesia and intensive care physicians and associated factors, Jurnalul Român de Anestezie Terapie Intensivă, Vol.19 Nr.2, 117-124.

10. Sîrghie R.E., lamandescu I.B. (2015), Factori biopsihosociali de risc profesional la personalul ATI, Rev. Medicală Română, vol. XII, nr. 3, p266-271.

11. Theorell T. (2012), Evaluating life events and chronic stressors în relation to health, $p$ 58-71 în Fava G.A., Sonino N. Wise T.N. (2012) - The psychosomatic Assessment - Kargel, Basel.
12. Maslach C. (1982), Burnout: The Cost of Caring, Prentice Hall, Englewood Cliffs, NJ. 13. Kielholz P., Pöldinger W., Adams C.

(1984), La depression masquée. Deutsche Ärtze Verlach, Köln.

14. Muntean Ana (2011), Cap. Rezilienţa, pp. 237-323 în Ana Muntean, Anca Munteanu - Violenţa, Trauma, Rezilienţa, Polirom, Iași. 